\title{
Intrapulmonary concentration of enrofloxacin in healthy calves
}

\author{
Konosuke OTOMARU ${ }^{1)}$, Masaya HIRATA ${ }^{1 \#}$, Tomonobu IKEDO $^{1)}$, Chie HORINOUCHI ${ }^{1)}$, Michiko NOGUCHI ${ }^{1)}$, \\ Shingo ISHIKAWA ${ }^{1)}$, Shun-ichi NAGATA ${ }^{2)}$ and Seiji $\mathrm{HOBO}^{1) *}$ \\ 1) Joint Faculty of Veterinary Medicine, Kagoshima University, 1-21-24 Korimoto, Kagoshima 890-0065, Japan \\ ${ }^{2)}$ Laboratory of Racing Chemistry, 1731-2 Tsuruta-machi, Utsunomiya, Tochigi 320-0851, Japan
}

(Received 2 September 2015/Accepted 13 November 2015/Published online in J-STAGE 13 December 2015)

\begin{abstract}
To determine the intrapulmonary concentration of enrofloxacin (ERFX) in calves, plasma, bronchoalveolar lavage fluid (BALF) and alveolar cells samples were obtained from clinically healthy calves. Four clinically healthy calves were administered a single dose of ERFX $(5 \mathrm{mg} / \mathrm{kg})$ by subcutaneous injection. Samples of plasma were obtained for each subjects at 0 (before administration), 1 and $2 \mathrm{hr}$ after administration of ERFX. Samples of BALF were obtained from each subject at 0,1 and $2 \mathrm{hr}$ after administration of ERFX. This examination was conducted two times, one week apart. The mean EFRX concentrations in plasma at 1 and $2 \mathrm{hr}$ after administration were 1.23 and 1.29 $\mu \mathrm{g} / \mathrm{ml}$, respectively. The mean EFRX concentrations in pulmonary epithelial lining fluid (ELF) at 1 and $2 \mathrm{hr}$ after administration $8.53 \mu \mathrm{g} /$ $\mathrm{m} l$ and $9.42 \mu \mathrm{g} / \mathrm{m} l$, respectively. The mean ERFX concentrations of alveolar cells in BALF at 1 and $2 \mathrm{hr}$ after administration were $4.04 \mu \mathrm{g} /$ $\mathrm{m} l$ and $5.19 \mu \mathrm{g} / \mathrm{m} l$, respectively. These results suggest that the ERFX concentrations in ELF and alveolar cells concentrations in BALF at 1 and $2 \mathrm{hr}$ after administration were higher than the plasma concentrations.
\end{abstract}

KEY WORDS: bronchoalveolar lavage fluid, calf, distribution, enrofloxacin, pulmonary epithelial lining fluid

doi: 10.1292/jvms.15-0495; J. Vet. Med. Sci. 78(4): 681-683, 2016

Bovine respiratory diseases consist of two types, alveolar pneumonia and interstitial pneumonia [1]. Pneumonia caused by bacterial and mycoplasma infection is mainly of the alveolar type [1]. Enrofloxacin (ERFX), one of the fluoroquinolones, has a broad spectrum of antimicrobial activity in vitro against the pathogens commonly associated with bovine respiratory diseases [7-9]. In order to treat alveolar pneumonia effectively with ERFX, it is necessary that administered ERFX reaches the intrapulmonary area and that the ERFX concentration achieves higher than the minimum inhibitory concentration (MIC) for target pathogenic microbes $[5,7-9,10]$. However, ERFX has been used for treatment of bovine respiratory diseases without knowledge about the intrapulmonary distribution in calves. Therefore, it is necessary to elucidate the distribution of ERFX in the intrapulmonary area in calves.

The purpose of this study was to elucidate the concentration of ERFX in bronchoalveolar lavage fluid (BALF) after administration in healthy calves.

Four 2-week-old clinically healthy Holstein bull calves with body weights of $50.6 \pm 3.9 \mathrm{~kg}$ (mean $\pm \mathrm{SD}$ ) were used in this study. The animals were cared for according to the Guide for the Care and Use of Laboratory Animals of the Joint Faculty of Veterinary Medicine, Kagoshima University. A single dose $(5 \mathrm{mg} / \mathrm{kg}$ ) of commercial ERFX (Baytril 5\%

*Correspondence to: Hobo S., Joint Faculty of Veterinary Medicine, Kagoshima University, 1-21-24 Korimoto, Kagoshima 890-0065, Japan. e-mail: k2088185@kadai.jp

\#These authors contributed equally to this work.

(C)2016 The Japanese Society of Veterinary Science

This is an open-access article distributed under the terms of the Creative Commons Attribution Non-Commercial No Derivatives (by-nc-nd) License $<$ http://creativecommons.org/licenses/by-nc-nd/4.0/>. injectable solution, Bayer, Tokyo, Japan) was administered to all calves by subcutaneous injection. Collection of body temperature, heart rate, respiratory rate and visual inspection data was conducted at 0 (before administration), 1, 2 and 3 $\mathrm{hr}$ after administration. In addition, peripheral blood samples were collected at 0 (before administration), 1, 2 and $3 \mathrm{hr}$ after administration via the jugular vein using heparinized tubes (VP-H050K, Terumo, Tokyo, Japan) and Vacutainer tubes (VP-NA052K, Terumo) containing dispotassium ethylenediaminetetraacetic acid (EDTA-2AK). This examination was conducted two times, one week apart.

Blood collected into tubes with EDTA-2AK was used for counting of white blood cells (WBCs) and red blood cells (RBCs) and hemoglobin $(\mathrm{Hb})$ and hematocrit $(\mathrm{Ht})$ analysis by automated cell counter (Poch-100iv, Sysmex, Kobe, Japan) within $1 \mathrm{hr}$ after collection.

Plasma was separated from blood collected into heparinized tubes by centrifugation and stored at $-70^{\circ} \mathrm{C}$ until analysis. BALF was collected at 0 (before administration), 1 and $2 \mathrm{hr}$ after administration of ERFX using a flexible electronic endoscope (VQ TYPE 5112B, Olympus, Tokyo, Japan). The upper airway of subjects was prepared for bronchoscopy by application of $2 \%$ lidocaine. The flexible electronic endoscope was inserted into a subsegment of each lobe. Two $50-\mathrm{m} l$ aliquots of sterile $0.9 \%$ normal saline solution were instilled into the lobe and immediately aspirated. The second aspiration was pooled with the first one. The volume of BALF was measured and recorded. BALF was collected from the left and right lobes in three places each, for a total of six places in the lung (right middle lobe, third bronchiole of the right caudal lobe, fifth bronchiole of the right caudal lobe, second bronchiole of the left caudal lobe, third bronchiole of the left caudal lobe and fifth bronchiole of the left caudal lobe). The BALF was immediately sent 
Table 1. Concentration of enrofloxacin in plasma, pulmonary epithelial lining fluid and alveolar cells at 0 , 1 and $2 \mathrm{hr}$ after administration of enrofloxacin

\begin{tabular}{|c|c|c|c|}
\hline & $0 \mathrm{hr}$ & $1 \mathrm{hr}$ & $2 \mathrm{hr}$ \\
\hline Enrofloxacin in plasma & N.D. & $1.23 \pm 0.22^{\mathrm{a}, \mathrm{b})}$ & $1.29 \pm 0.10^{\mathrm{d}, \mathrm{e})}$ \\
\hline Enrofloxacin in pulmonary epithelial lining fluid $(\mu \mathrm{g} / \mathrm{m} l)$ & N.D. & $8.53 \pm 2.48^{\mathrm{a}, \mathrm{c})}$ & $9.42 \pm 3.41^{\mathrm{d}, \mathrm{f})}$ \\
\hline Enrofloxacin in alveolar cells & N.D. & $4.04 \pm 1.62^{\mathrm{b}, \mathrm{c})}$ & $5.19 \pm 2.22^{\mathrm{e}, \mathrm{f})}$ \\
\hline
\end{tabular}

Data are shown as the mean \pm SD, N.D.: not detected. Value indicated with the same letters are significant different within the same sampling time (a-f: $P<0.01$ ).

to a laboratory for cell counting, and then, $1.5 \mathrm{~m} l$ of BALF was centrifuged at $400 \mathrm{~g}$ for $5 \mathrm{~min}$. The supernatant and cell pellets were separated and frozen at $-70^{\circ} \mathrm{C}$ until assays. All calves were used again after one week for the same procedure. The concentration of ERFX was measured by the high-performance liquid chromatography with tandem mass spectrometry (LC/MS/MS) method based on the previously established procedure reported by De Baere et al. [2]. Plasma samples $(100 \mu l)$ were diluted 10 times with distilled water. Each BALF cell pellet sample was mixed with 0.5 $\mathrm{m} l$ of 1 mol sodium hydroxide to lyse cells and then mixed with $1.0 \mathrm{~m} l$ of $3 \%$ formic acid. Three hundred microliters of each sample (diluted plasma, supernatant of BALF and lysed BALF cell pellet) was mixed with $60 \mu l$ of internal standard (Lomefloxacin, Sigma-Aldrich, Tokyo, Japan; $300 \mathrm{ng} / \mathrm{m} l$ in $1 \%$ formic acid/methanol (4:1)) and $60 \mu \mathrm{l}$ of methanol. The samples $(350 \mu l)$ were loaded into a solid-phase extraction column (Oasis HLB, Waters, Tokyo, Japan). The residue was dissolved in $250 \mu l$ of mobile phase. An aliquot $(10 \mu l)$ of the extract was injected into the LC/MS/MS (Prominence, Shimadzu, Kyoto, Japan; 4000 QTRAP, AB, Sciex, Tokyo, Japan). The average recovery rate was $81.5 \%$ for ERFX. The reproducibility was $1.6 \%$ for ERFX.

The ERFX concentration was determined in pulmonary epithelial lining fluid (ELF) and alveolar cells in BALF [4, 5]. The concentration of ERFX in ELF $\left(\right.$ ERFX $\left._{\text {ELF }}\right)$ was determined as follows:

$$
E R F X_{E L F}=E R F X_{B A L F} X \frac{\text { urea }_{\text {Plasma }}}{\text { urea }_{B A L F}} \text {, }
$$

where $E R F X_{B A L F}$ was the concentration of ERFX in BALF, urea $_{\text {Plasma }}$ is the concentration of urea in plasma, and urea $_{B A L F}$ is the concentration of urea in BALF.

The concentration of ERFX in alveolar cells $\left(\right.$ ERFX $\left._{\mathrm{AC}}\right)$ was determined as follows:

$$
E R F X_{A C}=\frac{A C_{P E L L E T}}{V_{A C}},
$$

where $A C_{P E L L E T}$ was the concentration of ERFX in the alveolar cell pellet and $V_{A C}$ was the mean volume of cattle BALF cells. A volume of $1.28 \mu l / 10^{6}$ BALF cells, devised in another bovine study, was used for the volume of BALF cells $[4,5]$.

Data are shown as the total values of the first and second examinations. Statistical analyses of data were conducted using analysis of variance (one-way ANOVA) followed by the Tukey-Kramer multiple comparison test to determine the difference in ERFX within the same sampling times.
All statistical analyses were performed using the IBM SPSS Statistics 21 software (IBM, Tokyo, Japan), and $P<0.05$ was considered statistically significant.

The body temperature, heart rates and respiratory rates of the calves hardly fluctuated, and abnormal clinical findings were not recognized by visual inspection during the experiment. The WBC, $\mathrm{RBC}, \mathrm{Hb}$ and $\mathrm{Ht}$ values of the calves hardly fluctuated during the experiment. The mean ERFX concentrations in plasma at 1 and $2 \mathrm{hr}$ after administration were $1.23 \mu \mathrm{g} / \mathrm{m} l$ and $1.29 \mu \mathrm{g} / \mathrm{m} l$, respectively (Table 1 ). The mean ERFX concentrations in ELF at 1 and $2 \mathrm{hr}$ after administration were $8.53 \mu \mathrm{g} / \mathrm{m} l$ and $9.42 \mu \mathrm{g} / \mathrm{ml}$, respectively, and the mean ERFX concentration in alveolar cells were 4.04 $\mu \mathrm{g} / \mathrm{m} l$ and $5.19 \mu \mathrm{g} / \mathrm{m} l$. The mean ERFX concentrations in ELF and alveolar cells at 1 and $2 \mathrm{hr}$ were significantly higher than those in plasma $(P<0.01)$.

The distribution of ERFX to the intrapulmonary area in dogs and horses has been reported $[6,12]$. In calves, the distribution of ERFX to plasma or serum after a single subcutaneous administration has been elucidated $[3,11]$, however, the distribution of ERFX to the intrapulmonary area has not been determined. Therefore, the aim of this study was to elucidate the distribution of ERFX to ELF and alveolar cells after a single subcutaneous administration of ERFX at $5 \mathrm{mg} / \mathrm{kg}$ to calves. We confirmed that ERFX was distributed into the ELF and alveolar cells in BALF at 1 and $2 \mathrm{hr}$ after administration. The ERFX concentrations in ELF and alveolar cells, which were above $4 \mu \mathrm{g} / \mathrm{m} l$, were higher than those in plasma concentrations. Previous studies reported that the $\mathrm{MIC}_{90}$ values of EFRX for Pasteurella multocida, Mannheimia haemolytica and Mycoplasma bovis were 0.31 $\mu \mathrm{g} / \mathrm{m} l, 0.50 \mu \mathrm{g} / \mathrm{ml}$ and $1.56 \mu \mathrm{g} / \mathrm{ml}$, respectively [7-9]. Although the data in the present study were obtained only at 1 and $2 \mathrm{hr}$ after subcutaneous administration, ERFX might be an effective antibacterial agent for pathogenic bacteria and mycoplasma intracellularly as well as extracellularly in the intrapulmonary area, judging from the high concentrations found in ELF and alveolar cells.

In the present study, the body temperature, heart rates and respiratory rates in calves did not fluctuate, and abnormal clinical findings were not recognized by visual inspection at before or after BALF collection. Therefore, BALF collection might be a safe and useful method in calves.

Further studies with continuous administration and longterm administration are needed to clarify distribution of ERFX to the intrapulmonary area after subcutaneous administration in calves. 


\section{REFERENCES}

1. Bryson, D. G. 1985. Calf pneumonia. Vet. Clin. North Am. Food Anim. Pract. 1: 237-257. [Medline]

2. De Baere, S., Goossens, J., Osselaere, A., Devreese, M., Vandenbroucke, V., De Backer, P. and Croubels, S. 2011. Quantitative determination of T-2 toxin, HT-2 toxin, deoxynivalenol and deepoxy-deoxynivalenol in animal body fluids using LC-MS/ MS detection. J. Chromatogr. B Analyt. Technol. Biomed. Life Sci. 879: 2403-2415. [Medline] [CrossRef]

3. de Lucas, J. J., San Andrés, M. I., González, F., Froyman, R. and Rodríguez, C. 2008. Pharmacokinetic behaviour of enrofloxacin and its metabolite ciprofloxacin after subcutaneous administration in cattle. Vet. Res. Commun. 32: 275-279. [Medline] [CrossRef]

4. Giguère, S., Huang, R., Malinski, T. J., Dorr, P. M., Tessman, R. K. and Somerville, B. A. 2011. Disposition of gamithromycin in plasma, pulmonary epithelial lining fluid, bronchoalveolar cells, and lung tissue in cattle. Am. J. Vet. Res. 72: 326-330. [Medline] [CrossRef]

5. Gotfried, M. H., Danziger, L. H. and Rodvold, K. A. 2001. Steady-state plasma and intrapulmonary concentrations of levofloxacin and ciprofloxacin in healthy adult subjects. Chest 119: 1114-1122. [Medline] [CrossRef]

6. Hawkins, E. C., Boothe, D. M., Guinn, A., Aucoin, D. P. and Ngyuen, J. 1998. Concentration of enrofloxacin and its active metabolite in alveolar macrophages and pulmonary epithelial lining fluid of dogs. J. Vet. Pharmacol. Ther. 21: 18-23. [Medline] [CrossRef]

7. Kato, T., Yamamoto, T., Ogata, Y., Urushiyama, Y., Ogino, S. and Saito, H. 2008. Clinical effectiveness of programs for treatment of respiratory diseases in cattle based on drug susceptibility. $J$. Jpn. Vet. Med. Assoc. 61: 294-298 (in Japanese). [CrossRef]

8. Katsuda, K., Kohmoto, M., Mikami, O. and Uchida, I. 2009. Antimicrobial resistance and genetic characterization of fluoroquinolone-resistant Mannheimia haemolytica isolates from cattle with bovine pneumonia. Vet. Microbiol. 139: 74-79. [Medline] [CrossRef]

9. Koike, S. and Usami, Y. 2011. Antimicrobial susceptibility of Mycoplasma bovis and analyses of domain V in $23 \mathrm{~S}$ ribosomal RNA of macrolide resistant strains. J. Jpn. Vet. Med. Assoc. 64: 45-49 (in Japanese).

10. Metzler, K., Hansen, G. M., Hedlin, P., Harding, E., Drlica, K. and Blondeau, J. M. 2004. Comparison of minimal inhibitory and mutant prevention drug concentrations of 4 fluoroquinolones against clinical isolates of methicillin-susceptible and -resistant Staphylococcus aureus. Int. J. Antimicrob. Agents 24: 161-167. [Medline] [CrossRef]

11. Scheer, M. 1987. Concentrations of active ingredient in Tmax the serum and tissues after oral and parenteral administration of Baytril. Vet. Med. Rev. 2: 104-118.

12. Winther, L. 2012. Antimicrobial drug concentrations and sampling techniques in the equine lung. Vet. J. 193: 326-335. [Medline] [CrossRef] 